DOI: 10.22630/EIOGZ.2014.107.31

Zeszyty Naukowe Szkoły Głównej Gospodarstwa Wiejskiego

Ekonomika i Organizacja Gospodarki Żywnościowej nr 107, 2014: 127-141

Michat Pietrzak

Wydział Nauk Ekonomicznych

Szkoła Główna Gospodarstwa Wiejskiego w Warszawie

Marcin Mucha

Związek Producentów Cukru w Polsce

\title{
Wpływ regulacji rynku na funkcjonowanie sektora cukrowniczego w Polsce
}

\section{Wstęp}

Światowa produkcja cukru w sezonie 2012/2013 wyniosła $183 \mathrm{mln}$ ton, przy czym blisko $80 \%$ tego produktu wytwarza się z trzciny cukrowej, resztę zaś z buraków cukrowych. Obecnie cukier produkuje się w 127 krajach świata (w 79 z trzciny cukrowej, a w 48 z buraków). Do największych producentów cukru z buraków cukrowych zalicza się Rosję, Stany Zjednoczone oraz kraje Unii Europejskiej, które łącznie produkują 17,2 mln ton, czyli 45\% światowego wolumenu cukru uzyskiwanego z buraków. Polska z produkcją 1,86 mln ton zajmuje 7. miejsce na świecie $\mathrm{w}$ rankingu największych producentów cukru $\mathrm{z}$ buraków cukrowych, wśród krajów UE zajmuje 3. pozycję z 10,4-procentowym udziałem w produkcji. Największymi producentami cukru z trzciny są natomiast Brazylia, Indie oraz Tajlandia, które łącznie produkują ponad 50\% światowego cukru z trzciny cukrowej [International Sugar... 2013]. Produkcja cukru w Polsce stanowi istotne źródło dochodów dla blisko 36 tys. plantatorów. Przemysł cukrowniczy zatrudnia 3,3 tys. osób. Bilansowe spożycie cukru wynosi około $41 \mathrm{~kg}$ per capita, z czego tylko około $38 \%$ konsumowane jest w formie bezpośredniej [Rynek Cukru... 2013]. Powyższe dane wskazują, iż sektor cukrowniczy jest istotną branżą polskiego agrobiznesu.

Przemysł cukrowniczy ze względu na swoją specyfikę posiada pewne cechy narażające go na tzw. morderczą konkurencję (cut-throat competition). Niektórzy ekonomiści uważają, że w tego typu sektorach interwencja państwa jest lep- 
szym rozwiązaniem niż koordynacja rynkowa. Celem artykułu jest zaprezentowanie ewolucji podejścia do regulacji przemysłu cukrowniczego począwszy od polskiej transformacji ustrojowej, ze szczególnym uwzględnieniem okresu po akcesji do Unii Europejskiej oraz ocena jej wpływu na funkcjonowanie krajowego sektora cukrowniczego w kontekście paradygmatu S-C-P (Structure-Conduct-Performance).

\section{Efektywność struktur rynkowych a interwencja w mechanizm rynkowy ze szczególnym uwzględnieniem sektora cukrowniczego w świetle literatury}

Zgodnie z popularną definicją L. Robbinsa, „Ekonomia jest nauką badającą ludzkie zachowania jako stosunek między celami i ograniczonymi środkami o alternatywnych zastosowaniach"1. Rzadkość środków rodzi konieczność dokonywania wyborów, wybór zaś implikuje koszty rozumiane jako rezygnacja z najlepszej niewybranej alternatywy. Zakłada się przy tym racjonalność ludzi, którą można sprowadzić do zasady maksymalizacji, tj. że człowiek będzie dążył do realizacji wyznaczonego celu zużywając najmniejszą możliwą ilość nakładów. Można zatem powiedzieć, że „Ekonomia zajmuje się efektywnością rynków w alokacji i koordynacji zastosowań zasobów" [Gorynia i in. 2005, s. 596]. Efektywność jest przy tym oceniana z perspektywy danego rynku/sektora ${ }^{2}$ i rozumiana jako maksymalna możliwa do osiagnięcia łączna nadwyżka producenta i konsumenta, lub z perspektywy całej gospodarki i rozumiana jako maksymalizacja dobrobytu społecznego.

Synteza teorii marginalnej z dorobkiem klasyków dokonana przez Marshalla doprowadziła do powstania ekonomii neoklasycznej, w ramach której rozwinięto teorię konkurencji oraz teorię monopolu. W ramach tych dwóch form organizacji rynku pożądaną strukturą rynkową jest doskonała konkurencja $\mathrm{z}$ atomistyczną strukturą nabywców i dostawców pozbawionych siły rynkowej, a monopol jest przejawem nieefektywnej struktury [Scherer 1970, s. 4-5, 8-11, Carlton i Perloff 2005, s. 2-4]. Według ekonomii neoklasycznej, w sektorze konkurencyjnym swobodny proces ustalania cen towarów i usług oraz czynników produkcji

\footnotetext{
${ }^{1}$ Cyt. za: R. Coase. 2013: Firma, rynek i prawo, Oficyna Wolters Kluwer Business, Warszawa 2013, s. 1.

${ }^{2}$ Szerszą dyskusje na temat pojęć rynku i sektora zob. M. Pietrzak, 2014: Problem geograficznego zakresu rynków/sektorów w dobie globalizacji i regionalizacji, Zagadnienia Ekonomiki Rolnej nr 1, s. 3-4.
} 
w połączeniu ze swobodą zachowań producentów i konsumentów powodują że społeczeństwo wytwarza z posiadanych zasobów maksimum korzyści. Według Marshalla, ,teoria konkurencji uzupełniona teorią monopolu dostarczała kompletnego wyposażenia ekonomicznej »skrzynki z narzędziami «niezbędnymi do analizy współczesnego przemysłu" [Blaug 2000, s. 402-403]. Tezę tę podważył Chamberlin, publikując w 1933 roku Theory of Monopolistic Competition. Wprowadzając odmienny typ struktur rynkowych - konkurencję monopolistyczną, autor ten dokonał ,przewrotu”, który ,polegał na zwielokrotnieniu liczby struktur rynkowych, które musi analizować ekonomia" [Blaug 200, s. 203-204].

Wykorzystanie teorii mikroekonomii do badań empirycznych rynków i sektorów doprowadziło do powstania dyscypliny zwanej ekonomią branży. Na tle mikroekonomii ekonomia branży charakteryzuje się bardziej praktycznym, bliższym rzeczywistości ujęciem zjawisk gospodarczych [Carlton i Perloff 2005, s. 2]. Kluczowym podejściem badawczym wypracowanym przez ekonomię branży jeszcze w latach 30. ubiegłego wieku jest paradygmat S-C-P. Model ten jest również określany jako koncepcja Baina - Masona od nazwisk jej twórców lub jako „szkoła harwardzka” [Tirole 1988, s. 1].

Zgodnie z modelem S-C-P (Structure-Conduct-Performance) struktura ryn$\mathrm{ku} /$ sektora determinuje zachowania przedsiębiorstw, a w konsekwencji efektywność rynku/sektora, przy czym [Scherer 1970, s. 4-5, 8-11, Carlton i Perloff 2005, s. 2-4, Porter 1981, s. 611]:

- $\quad$ struktura (Structure) jest rozumiana jako względnie trwałe ekonomiczne i techniczne wymiary sektora, a w szczególności: bariery wejścia do sektora, liczba i rozkład wielkości firm, zróżnicowanie produktu, elastyczność popytu,

- zachowanie (Conduct) to wybory przedsiębiorstw w zakresie takich zmiennych decyzyjnych jak ceny, reklama, moce produkcyjne, jakość - można to pojęcie utożsamić z ekonomicznym wymiarem strategii firm,

- efektywność rynku/sektora (Performance) jest rozumiana w kategoriach dobrobytu społecznego, a w szczególności jako efektywności techniczna i alokacyjna, stabilność cen oraz innowacyjność.

Ze względu na swój bardziej empiryczny charakter w stosunku do mikroekonomii i koncentrację na prawdziwych rynkach ekonomia branży wypełniła lukę pomiędzy teorią ekstremalnych form rynku, tj. konkurencją doskonała, a monopolem - na których koncentrują się tradycyjnie ekonomiści [Porter 1981, s. 611]. Nie zmienia to faktu, że logika normatywna modelu S-C-P jest taka sama jak neoklasycznej teorii cen: ideałem jest doskonała konkurencja, a im bardziej struktura rynku od niego odbiega, tym mniej dobrobytu osiąga społeczeństwo [Scherer 1970, s. 4-5, 8-11, Carlton i Perloff 2005, s. 2-4]. 
Z modelu S-C-P wynika, że różnice pomiędzy strukturami sektorów powinny wyjaśniać różnice w efektywności ( $w$ tym rentowności ${ }^{3}$ ) sektorów. Prawdziwość tego twierdzenia była weryfikowana w bardzo licznych badaniach, których przegląd można znaleźć między innymi w opracowaniach Schmalensee oraz Lee [Schmalensee 1989, Lee 2007]. Warto przy tym podkreślić, że tradycyjnie badacze koncentrują się na relacji między strukturą a efektywnością [Carlton i Perloff 2005, s. 244] - de facto posługują się więc modelem S-P.

W pierwotnym ujęciu model Baina - Masona był rozumiany jako zależność: S-> C-> P. Późniejsi autorzy krytykują statyczność i determinizm ekonomii branży w tradycyjnym podejściu, w którym struktura jest traktowana jako stabilna zmienna egzogeniczna, podczas gdy menedżerowie dążą do wpływania na nią i jej zmiany poprzez swoje działania, np. zwiększając stopień koncentracji sektora, tworząc bariery wejścia na rynek itp. [Porter 1981, s. 615-616]. W bardziej współczesnych ujęciach modelu S-C-P uchyla się założenie o statyczności i egzogeniczności struktury [Scherer 1970, s. 5, Carlton i Perloff 2005, s. 4], wprowadza się również dodatkowe zmienne: podstawowe uwarunkowania oraz politykę rządu (rys. 1).

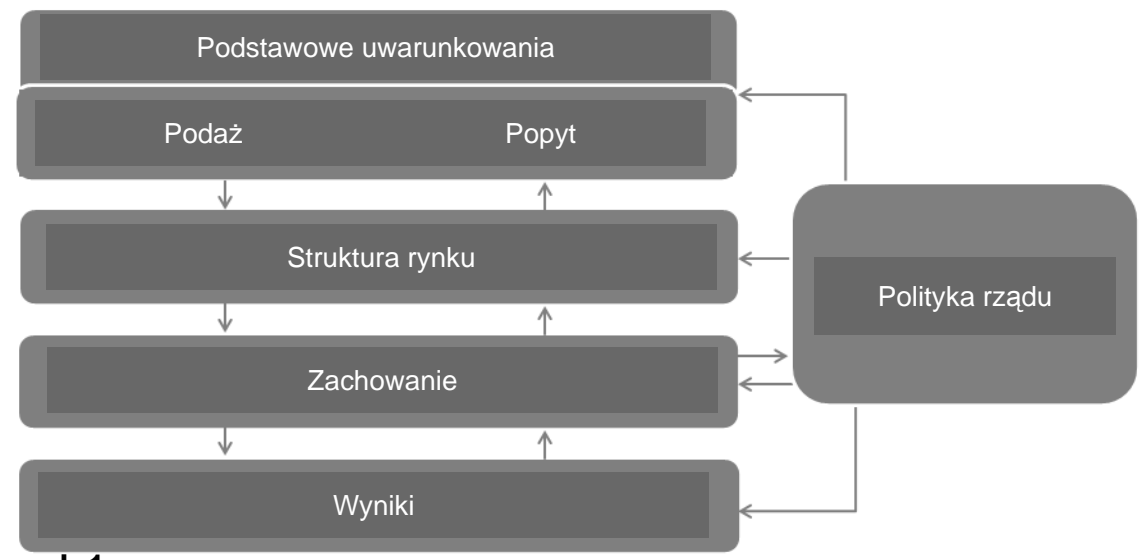

\section{Rysunek 1}

Rozszerzony model S-C-P

Źródło: Scherer 1970 s. 5, Carlton i Perloff 2005, s. 4.

Wprowadzenie polityki rządu jako dodatkowej zmiennej jest istotnym rozszerzeniem modelu z punktu widzenia analiz dotyczących rolnictwa i gospodarki żywnościowej. Produkcja rolnicza ze względu na swoje uwarunkowania przyrodnicze podlega wahaniom, czasem znacznym. Przy względnie nieelastycznym popycie na żywność, może prowadzić to do gwałtownych wahań cen, co z kolei

\footnotetext{
${ }^{3}$ Należy przy tym zaznaczyć, że zgodnie z założeniami ekonomii neoklasycznej zysk ekonomiczny wyższy od zera jest interpretowany jako przejaw siły rynkowej, a więc odejście od ideału konkurencji i w konsekwencji - symptom nieefektywności rynku/sektora.
} 
może zakłócać efektywność alokacji zasobów, szczególnie tam, gdzie mobilność zasobów jest ograniczona ${ }^{4}$.

W ramach ekonomii branży funkcjonuje pojęcie tzw. morderczej konkurencji (cut-throat competition). Problem „,morderczej konkurencji” dotyczy dwóch typów rynków: sektorów z chronicznym nadmiarem mocy produkcyjnych oraz rynków podlegających gwałtownym fluktuacjom - cyklicznym lub losowym. Część ekonomistów uważa, że w tego typu sektorach interwencja państwa jest lepszym rozwiązaniem niż bazowanie na rynkowej koordynacji poprzez mechanizm cenowy [Scherer 1970, s. 198-199].

Cukrownictwo, podobnie jak inne działy agrobiznesu - zwłaszcza związane z produkcją roślinna, w których ekspozycja na ryzyko przyrodnicze jest znaczna - podlega dużym fluktuacjom, co naraża je na tzw. morderczą konkurencję. Co więcej, specyfika przemysłu cukrowniczego, w którym kampania trwa przez niespełna 1/3 roku - wskazuje na swego rodzaju nadmiar mocy produkcyjnych, który sprzyja presji na zapewnienie sprzedaży, nawet kosztem zysków - celem pokrycia choćby części kosztów stałych [Potrer 1998, s. 35-36].

Czy i na ile wymaga to interwencji państwa w mechanizm rynkowy pozostaje otwartym i wciąż nie w pełni rozstrzygniętym problemem. Uszczegółowionym wariantem tego zagadnienia jest pytanie o zasadność, skuteczność i efektywność stosowanych w UE, w tym w Polsce - od momentu akcesji - mechanizmów wspólnej organizacji rynku cukru oraz jej reform. Ważnym kontekstem tej dyskusji jest fakt specyfiki żywności jako produktu i jej strategicznego znaczenia wyrażanego w pojęciu bezpieczeństwa żywnościowego państwa. Krytycy interwencji wskazują jednak, że państwo nie jest bytem wszechwiedzącym ani omnipotentnym, ulega presji wynikającej z pogoni za rentami politycznymi. Kwestie te poddają w watpliwość czy państwo jest w stanie doprowadzić do bardziej efektywnej alokacji rzadkich zasobów niż konkurencyjny rynek. Stąd też ważnym nurtem rozważań ekonomicznych wydają się badania dotyczące regulacji stosowanych wobec sektora cukrowniczego i ich ewolucji, ze szczególnym uwzględnieniem okresu po akcesji Polski do UE oraz ich wpływu na funkcjonowanie sektora. Naturalne wydaje się w tym zakresie wykorzystanie paradygmatu S-C-P.

Polskie cukrownictwo w swojej blisko 200-letniej historii doczekało się licznych publikacji oraz opracowań. Nie ma jednak zbyt obszernej literatury ${ }^{5}$ opisującej kompleksowo ten sektor w kontekście zmieniających się uwarunko-

\footnotetext{
${ }^{4}$ Por. również: A. Czyżewski, A. Poczta-Wajda, 2011: Polityka rolna w warunkach globalizacji. Doświadczenia GATT/WTO, Polskie Wydawnictwo Ekonomiczne, Warszawa, s. 16, 24.

${ }^{5}$ Okresowe analizy i raporty rynkowe przygotowywane przez Instytut Ekonomii Rolnictwa i Gospodarki Żywnościowej - PIB oraz zespół monitoringu rynków rolno-spożywczych FAMMU/ /FAPA są niezwykle cennym materiałem źródłowym, ale z natury rzeczy nie podejmują problematyki w ujęciu długookresowym.
} 
wań prawnych na przestrzeni ostatniego ćwierćwiecza. Wśród kluczowych publikacji, które w sposób holistyczny analizują rynek cukru w Polsce po 1989 roku, można wymienić monografie Kondrakiewicz [2000] oraz Iwana [2007].

Kondrakiewicz koncentruje się na branżowych regulacjach prawnych, w szczególności tzw. ustawie cukrowej z 1994 roku i ich wpływie na kształt rynku cukru oraz strategie funkcjonujących na nim holdingów. Poddaje ocenie skuteczność przyjętych rozwiązań pod kątem nadrzędnego celu, jakim było przygotowanie sektora do integracji z UE. Iwan skupia się na procesach prywatyzacyjnych i restrukturyzacyjnych branży od początku lat 90 . do momentu akcesji do UE, ze szczególnym uwzględnieniem konsekwencji, jakie na kształt i funkcjonowanie rynku cukru w Polsce wywarło pojawienie się inwestorów zagranicznych.

Oprócz wspomnianych monografii warto w sposób szczególny odnotować publikacje Chudoby [2010], Artyszaka [2009], Szajnera [2009], Muchy [2010], którzy w swoich pracach dokonują oceny wpływu reformy regulacji rynku cukru przeprowadzonej w Unii Europejskiej w latach 2006-2010 na sektor cukrowniczy w Polsce. Żadna z powyższych publikacji nie wykorzystywała modelu S-C-P jako podstawy metodycznej badań. Model ten był zastosowany w analizie rynku cukru do jakościowego opisu sytuacji producentów buraków cukrowych oraz przetwórstwa cukru, która jednakże dotyczyła lat 90. ubiegłego wieku [Woszczyna i Wyszyński 2000, s. 376-378, 382-384].

\section{Regulacja rynku cukru i jej ewolucja}

Pierwsze regulacje prawne dotyczące cukrownictwa pojawiły się w Polsce już w latach 20. XX wieku. W okresie PRL cukrownie były w pełni uzależnione od polityki ekonomicznej państwa, które mogło decydować o wysokości produkcji i cenie produktu z pominięciem czynników stricte ekonomicznych i niekiedy w celu realizacji potrzeb politycznych [Wykrętowicz 1997, s. 343]. Odejście od gospodarki planowanej na rzecz gospodarki wolnorynkowej na przełomie roku 1989/1990 oraz późniejsze wejście Polski do Unii Europejskiej wiązało się $\mathrm{z}$ wieloma istotnymi zmianami otoczenia regulacyjnego przedsiębiorstw cukrowniczych. Zmiany te w pewnym uproszczeniu można podzielić na trzy okresy (syntetyczne porównanie głównych mechanizmów regulacyjnych zastosowanych na rynku cukru zawiera tabela 1).

\section{Okres I (1990/91-1993/94)}

Ignorowanie reguł podaży i popytu oraz niska efektywność gospodarcza spowodowały, że zakłady produkcyjne działające w Polsce w chwili uzyskania samodzielności na początku lat 90 . nie były przygotowane na konkurencję 
Tabela 1

Porównanie głównych mechanizmów regulacyjnych i interwencyjnych na rynku cukru w latach 1990/1991-2012/2013

\begin{tabular}{|c|c|c|c|c|c|}
\hline \multirow[b]{2}{*}{$\begin{array}{l}\text { Wyszczegól- } \\
\text { nienie }\end{array}$} & \multirow[b]{2}{*}{$\begin{array}{l}\text { Okres I } \\
(90 / 91- \\
-93 / 94)\end{array}$} & \multicolumn{2}{|c|}{ Okres II } & \multicolumn{2}{|c|}{ Okres III } \\
\hline & & $\begin{array}{c}\text { Ila } \\
(94 / 95- \\
-00 / 01)\end{array}$ & $\begin{array}{c}\mathrm{Ilb} \\
(01 / 02- \\
-03 / 04)\end{array}$ & $\begin{array}{c}\text { IIIa } \\
(04 / 05- \\
-05 / 06)\end{array}$ & $\begin{array}{c}\text { IIIb } \\
(06 / 07- \\
-12 / 13)\end{array}$ \\
\hline $\begin{array}{l}\text { Limity } \\
\text { produkcyjne }\end{array}$ & Brak & \multicolumn{3}{|c|}{$\begin{array}{l}\text { Kwota krajowa A oraz kwoty eksportowe B } \\
\text { i C (od } 2004 \text { - dotycza eksportu poza UE) }\end{array}$} & $\begin{array}{l}\text { Limit krajowy } \\
\text { - cukier kwo- } \\
\text { towy }\end{array}$ \\
\hline Ochrona rynku & \multicolumn{3}{|c|}{ Krajowe cła importowe } & \multicolumn{2}{|c|}{ Unijne cła importowe } \\
\hline $\begin{array}{l}\text { Dopłaty } \\
\text { do eksportu }\end{array}$ & Tak - ARR & \multicolumn{3}{|c|}{ Tak - finansowane przez branżę } & $\begin{array}{l}\text { Zawieszone } \\
\text { (od 2008) }\end{array}$ \\
\hline Regulacja cen & Brak & \multicolumn{2}{|c|}{$\begin{array}{l}\text { Buraki - minimalna, cukier } \\
\text { - minimalna }\end{array}$} & $\begin{array}{l}\text { Buraki - mini- } \\
\text { malna, cukier } \\
\text { - interwen- } \\
\text { cyjna }\end{array}$ & $\begin{array}{l}\text { Buraki - mini- } \\
\text { malna, cukier } \\
\text { - referen- } \\
\text { cyjna }\end{array}$ \\
\hline $\begin{array}{l}\text { Regulacja } \\
\text { struktury pod- } \\
\text { miotowo- } \\
\text {-własnościowej }\end{array}$ & \begin{tabular}{|l} 
Rozpro- \\
szone \\
cukrownie \\
państwowe, \\
marginalna \\
prywatyzacja
\end{tabular} & $\begin{array}{l}4 \text { holdingi } \\
\text { państwowe } \\
\text { inkorporujące } \\
\text { cukrownie/ } \\
\text { /marginalna } \\
\text { prywatyzacja }\end{array}$ & \begin{tabular}{|l|} 
Prywaty- \\
zacja, kon- \\
solidacja, \\
powołanie \\
podmiotu \\
narodowego
\end{tabular} & \multicolumn{2}{|c|}{$\begin{array}{l}\text { Wykluczone wejście nowych } \\
\text { podmiotów }\end{array}$} \\
\hline
\end{tabular}

Źródło: Opracowanie własne.

rynkową. Tymczasem w pierwszych latach transformacji podstawowe kwestie dotyczące funkcjonowania branży zostały pozostawione w zasadniczej mierze wolnorynkowym regułom gospodarczym, a nieliczne regulacje, np. możliwość interwencji państwowej, wynikały z systemowych regulacji dotyczących całej gospodarki rolno-spożywczej. Podmioty gospodarcze działające w branży zostały poddane decentralizacji, wskutek czego liczba przedsiębiorstw wzrosła z 13 do 78. Jednak nadal funkcjonowały one w formie przedsiębiorstw państwowych. Pojawiające się na początku lat 90. problemy nadprodukcji były rozwiązywane przez skup interwencyjny cukru (np. w kampanii 1990/91 10\% produkcji) oraz dopłaty do eksportu wypłacane przez Agencję Rynku Rolnego (ARR) w szczególności w okresie kampanii 1991/92. Brak regulacji prawnych dotyczących produkcji cukru nie miał bezpośredniego wpływu na sytuację podażową na rynku. Stosunkowo duże wahania produkcji (przy średnim poziomie ok. 1,7 mln ton) były spowodowane dużą zmiennością plonowania buraków cukrowych i powierzchni ich upraw oraz zmiany jakościowej surowca [Urban 1995, s. 16-17]. Wysokość taryf celnych przesądzała o znikomym zainteresowaniu importem. 


\section{Okres II (lata 1994/95-2003/04)}

Pierwsze kompleksowe regulacje sektora cukrowniczego przyjęto w 1994 roku wraz z tzw. ustawą cukrową ${ }^{6}$, która wprowadzała wiele rozwiązań branżowych oraz określała porządek organizacyjny sektora powołując do życia cztery holdingi cukrownicze, do których miały być inkorporowane przedsiębiorstwa (wówczas praktycznie tożsame z zakładami-cukrowniami). Kształt regulacji był wzorowany na prawie UE i opierał się na limitowaniu podaży przez administracyjnie przyznawane kwoty produkcyjne, wprowadzeniu cen urzędowych oraz dopłat do eksportu. System kwotowy miał zapewnić stabilizację podaży na poziomie odpowiednim do potrzeb rynku krajowego [Kondrakiewicz 2000].

Kwoty zostały podzielone na dwa typy: kwota A na potrzeby rynku wewnętrznego, kwota B obejmowała cukier przeznaczony na eksport z refundacjami. Dopłaty te stopniowo stawały się coraz niższe i dotyczyły mniejszego wolumenu, co było konsekwencją przyjęcia postanowień Rundy Urugwajskiej GATT. Nowelizacja ustawy z 1997 roku wprowadziła pojęcie kwoty C, czyli nadwyżkowych ilości cukru przekraczających kwoty A i B, przeznaczonych na eksport bez jakichkolwiek dopłat. Import cukru przy obowiązujących wysokich stawkach celnych był znikomy.

Punktem zwrotnym w okresie II była przyjęta w 2001 roku ustawa o regulacji rynku cukru ${ }^{7}$. System kwotowania produkcji z pewnymi modyfikacjami został utrzymany, wprowadzono cenę interwencyjną oraz jednolite dla całego kraju ceny minimalne na buraki cukrowe. Cena interwencyjna, która została ustalona przez ARR, była jednocześnie ceną minimalną, poniżej której cukier nie mógł być sprzedany innym kontrahentom. Rozpoczęto procesy prywatyzacyjne z udziałem inwestorów zagranicznych, co przyczyniło się do zamykania nierentownych zakładów produkcyjnych, reorganizacji pozostałych, zmian w polityce surowcowej oraz w zarządzaniu.

\section{Okres III (2004/05-2012/13)}

Wraz z akcesją Polski do UE przedsiębiorstwa cukrownicze stały się częścią unijnej wspólnej organizacji rynku. Do najważniejszych mechanizmów regulujących rynek cukru w UE w momencie akcesji Polski należały: kwoty produkcyjne, ceny urzędowe obejmujące cenę interwencyjną na cukier oraz gwarantowaną cenę minimalną na buraki cukrowe, dopłaty do eksportu stanowiące

\footnotetext{
${ }^{6}$ Ustawa z dnia 26 sierpnia 1994 r. o regulacji rynku cukru i przekształceniach własnościowych w przemyśle cukrowniczym (Dz.U. z 1994 r. Nr 98, poz. 473, z późn. zm.)

${ }^{7}$ Dz.U. z 2001 r. Nr 76, poz. 810.
} 
różnicę pomiędzy ceną interwencyjną a ceną na rynku światowym, system ceł importowych oraz kontyngentów obejmujący cały obszar UE.

Do czasu reformy system kwot obejmował produkcję cukru w ramach kwoty A i kwoty B, które miały zbliżony charakter do kwot A (blisko 1580 tys. t) i B (92 tys. t) w okresie II, z tym że dopłaty do eksportu w przypadku kwoty B dotyczyły eksportu poza UE. Nadwyżkowy cukier (powyżej kwot A i B) określano jako cukier $\mathrm{C}$ - musiał być wyeksportowany poza UE bez dopłat. Wysokie taryfy celne (419 euro/t cukru białego) miały chronić rynek przed importem, który aż do momentu wprowadzenia w życie reformy stanowił niewielką część podaży na rynku krajowym.

Przeprowadzona w latach 2005/06-2009/10 reforma wynikała ze zobowiązań międzynarodowych obejmujących porozumienia dotyczące dostępu do rynku dla krajów najbiedniejszych (LDC) i krajów Afryki, Karaibów i Pacyfiku (AKP) oraz orzeczenia WTO z kwietnia 2005 roku, w którym uznano, że Unia Europejska wbrew regułom handlu międzynarodowego w sposób pośredni subwencjonuje eksport cukru [Mucha 2010, s. 65]. Głównym założeniem reformy było dobrowolne ograniczenie produkcji o $6 \mathrm{mln}$ ton [Artyszak 2009, s. 5], co w efekcie miało doprowadzić do eliminacji nadwyżek, zapewnienia stabilizacji rynku oraz zwiększenia konkurencyjności przedsiębiorstw produkujących cukier. W tym celu ograniczono uprawę buraków i produkcję cukru, obniżono ceny referencyjne cukru i ceny skupu za surowiec. Decyzja WTO ustanowiła limit eksportowy na cukier pozakwotowy, a w 2008 roku Komisja Europejska zawiesiła dopłaty do eksportu cukru. W efekcie reformy nastapiła redukcja kwot produkcyjnych, zmniejszyła się produkcja oraz eksport, zwiększył się natomiast import. Polska od kampanii 2008/2009 stała się importerem netto cukru.

\section{Wpływ regulacji na funkcjonowanie sektora}

W części empirycznej opracowania wykorzystano uproszczoną relację Structure-Performance (S-P), co jak wspomniano jest typowe w badaniach opartych na paradygmacie S-C-P, uwzględniając jednakże dodatkowo wpływ czynnika polityki jako źródła regulacji rynku (rys. 2-4).

Nieprzyjęcie w okresie I odpowiednich regulacji prawnych na poziomie branżowym oraz polityczne decyzje o zaniechaniu przeprowadzenia szybkiej prywatyzacji skutkowało utrzymaniem niskiej efektywności ekonomicznej cukrowni spowodowanej silnym rozdrobnieniem przemysłu, małymi zdolnościami przerobowymi zakładów, przestarzałą technologią, nadmiernym zatrudnieniem oraz wysokimi kosztami produkcji cukru. Bardzo niska wydajność pracy utrzymywała się przez cały omawiany okres i wynosiła średnio 68 ton cukru na jednego zatrudnionego w cukrownictwie (rys. 2). 


\begin{tabular}{|c|c|}
\hline Struktura rynku & \multirow[b]{2}{*}{ I: Polityka rządu } \\
\hline $\begin{array}{ll}\text { liczba przedsiębiorstw: } & \text { wzrost z } 13 \text { do } 78 \\
\text { średnia skala } & \text { spadek ze } 157 \text { do } \\
\text { przedsiębiorstw: }\end{array}$ & \\
\hline Wyniki & $\begin{array}{l}\text { „prawie wolny rynek” } \\
\text { - brak regulacji }\end{array}$ \\
\hline $\begin{array}{ll}\text { ceny: } & \text { wzrost cen } \\
\text { wydajność pracy: } & 68 \text { t/os. } \\
\text { wykorzystanie zasobów } & \text { spadek z 96 do } \\
\text { (długość kampanii): } & 85 \text { dni }\end{array}$ & $\begin{array}{ll} & \text { branżowych } \\
\text { - } & \text { interwencja ARR } \\
\text { decentralizacja przy } \\
\text { zachowaniu } \\
\text { własności } \\
\text { państwowej }\end{array}$ \\
\hline
\end{tabular}

\section{Rysunek 2}

Wpływ polityki rządu na sektor cukrowniczy: okres I

Źródło: Opracowanie własne na podstawie „Rynek cukru. Stan i perspektywy” (nr 1, 3, 6, 8, 12, 30, 33, 37, 40); Rocznik Statystyczny Przemysłu GUS (1992-1998, 2000-2003); C. Iwan, 2007: The Impact of Privatization With Foreign in Volvement on the Restructuring Process of the Sugar Industry in Poland, Peter Lang Publishing Inc.

Brak działań holdingów ukierunkowanych na poprawę efektywności ekonomicznej czy restrukturyzację utrwalił silne rozdrobnienie branży. Dopiero ustawa z 2001 roku, która z jednej strony wyeliminowała niektóre niekorzystne przepisy budzące obawy, że likwidacja zakładu będzie się wiązała się z utratą kwoty [Iwan 2007, s. 250], a z drugiej pozwoliła na szerszy udział inwestorów z kapitałem zagranicznym w prywatyzacji, przyspieszyła procesy restrukturyzacyjne i konsolidacyjne. Zamykanie nierentownych zakładów produkcyjnych, zwiększanie mocy przerobowych pozostałych cukrowni, zmiany w polityce surowcowej oraz zarządzaniu miały wpływ na koncentrację produkcji w najbardziej efektywnych zakładach produkcyjnych. Skupienie udziałów w rynku cukru w rękach zaledwie kilku podmiotów spowodowało, że jego struktura w Polsce w przededniu akcesji do UE nabrała cech oligopolu (rys. 3).

Akcesja do Unii Europejskiej spowodowała przyjęcie obowiązujących w niej reguł prawnych. Kształt regulacji był w pewnym stopniu tożsamy z dotychczasowym systemem prawnym obowiązującym w Polsce, jednak istotne różnice, np. wyższa cena minimalna na buraki cukrowe, zmieniały w sposób kluczowy uwarunkowania funkcjonowania cukrowni. Okres pierwszych dwóch lat funkcjonowania w Unii Europejskiej był korzystny dla branży cukrowniczej. Przedsiębiorstwa korzystały z dogodnych przepisów systemu oraz konsekwencji z nich wynikających, w szczególności ze swobodnego przepływu towarów w ramach UE, wsparcia finansowego dla eksportu cukru poza granice UE oraz wysokich ceny zbytu na rynku krajowym (rys. 3). 


\begin{tabular}{|c|c|}
\hline \multicolumn{2}{|c|}{ Struktura rynku } \\
\hline $\begin{array}{l}\text { liczba przedsiębiorstw: } \\
\text { średnia skala } \\
\text { przedsiębiorstw: }\end{array}$ & $\begin{array}{l}\text { stabilizacja (76) } \\
\text { wzrost z } 18 \text { do } 118 \\
\text { kt }\end{array}$ \\
\hline Wyn & \\
\hline $\begin{array}{l}\text { ceny: } \\
\text { wydajność pracy: } \\
\text { wykorzystanie zasobów } \\
\text { (długość kampanii): }\end{array}$ & $\begin{array}{l}\text { duże wahania } \\
\text { spadek z } 68 \text { do } 50 \\
\text { t/os. } \\
\text { spadek z } 61 \text { do } 57 \\
\text { dni }\end{array}$ \\
\hline $\begin{array}{l}\text { rentowność } \\
\text { przychodów: }\end{array}$ & +/- ; średnio 1,9\% \\
\hline
\end{tabular}

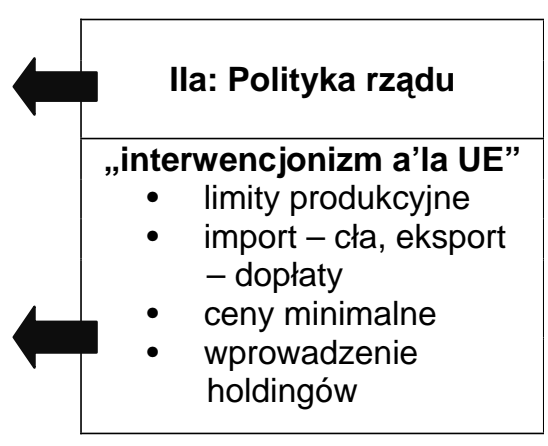

\begin{tabular}{|c|c|}
\hline \multicolumn{2}{|c|}{ Struktura rynku } \\
\hline $\begin{array}{l}\text { liczba przedsiębiorstw: } \\
\text { średnia skala } \\
\text { przedsiębiorstw: }\end{array}$ & $\begin{array}{l}\text { spadek z } 76 \text { do } 5 \\
\text { wzrost ze } 118 \text { do } \\
390 \text { kt }\end{array}$ \\
\hline \multicolumn{2}{|c|}{ Wyniki } \\
\hline ceny: & spadek cen \\
\hline wydajność pracy: & $\begin{array}{l}\text { wzrost z } 50 \text { do } \\
123 \text { t/os. }\end{array}$ \\
\hline $\begin{array}{l}\text { wykorzystanie zasobów } \\
\text { (długość kampanii): }\end{array}$ & $\begin{array}{l}\text { wzrost z } 49 \text { do } 62 \\
\text { dni }\end{array}$ \\
\hline $\begin{array}{l}\text { rentowność } \\
\text { przychodów }\end{array}$ & +/- ; średnio $2,2 \%$ \\
\hline
\end{tabular}

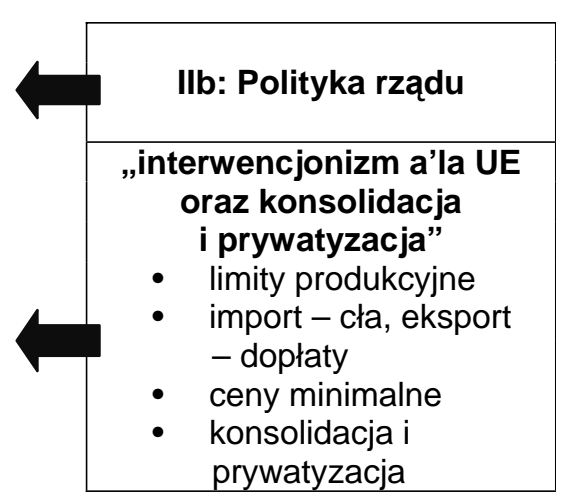

\section{Rysunek 3}

Wpływ polityki rządu na sektor cukrowniczy: okres II Źródło: Jak na rysunku 2.

Najważniejszy wpływ na zmianę sytuacji branży cukrowniczej miała reforma regulacji rynku cukru przeprowadzona w latach 2005/06-2009/10, zakładająca silną restrukturyzację branży w całej Europie. Jej efektem była redukcja kwot produkcyjnych (dla Polski wynosi ona obecnie 1,4 mln t i jest niższa od poziomu spożycia krajowego), mniejszy eksport przy większym imporcie (m.in. wskutek liberalizacji rynku dla cukru z krajów AKP/LDC), mniejsza produkcja, koncentracja bazy surowcowej, redukcja liczby cukrowni i zatrudnienia oraz koncentracja produkcji. W konsekwencji tych zmian branża cukrownicza w Polsce stała się bardziej skonsolidowana i wydajna. Efektem reformy był znaczący spadek zatrudnienia, który w rezultacie przyczynił się do rekordowego wzrostu wydajności pracy (ośmiokrotny wzrost w stosunku do 1990 roku). Restrukturyzacja 


\begin{tabular}{|c|c|}
\hline \multicolumn{2}{|c|}{ Struktura rynku } \\
\hline $\begin{array}{l}\text { liczba przedsiębiorstw: } \\
\text { średnia skala } \\
\text { przedsiębiorstw: }\end{array}$ & $\begin{array}{l}\text { stabilizacja (5) } \\
\text { stabilizacja } \quad(\sim 400 \\
\text { kt) }\end{array}$ \\
\hline Wyn & \\
\hline $\begin{array}{l}\text { ceny: } \\
\text { wydajność pracy: } \\
\text { wykorzystanie zasobów } \\
\text { (długość kampanii): }\end{array}$ & $\begin{array}{l}\text { wzrost } \\
\text { wzrost z } 168 \text { do } \\
211 \text { t/os. } \\
\text { wzrost z } 77 \text { do } 81 \\
\text { dni }\end{array}$ \\
\hline $\begin{array}{l}\text { rentowność } \\
\text { przychodów: }\end{array}$ & +/- ; średnio 5,8\% \\
\hline
\end{tabular}

\begin{tabular}{|c|c|}
\hline \multicolumn{2}{|c|}{ Struktura rynku } \\
\hline $\begin{array}{l}\text { liczba przedsiębiorstw: } \\
\text { średnia skala } \\
\text { przedsiębiorstw: }\end{array}$ & $\begin{array}{l}\text { stabilizacja (5) } \\
\text { stabilizacja } \quad(\sim 370 \\
\text { kt) }\end{array}$ \\
\hline Wyn & \\
\hline $\begin{array}{l}\text { ceny: } \\
\text { wydajność pracy: } \\
\text { wykorzystanie zasobów } \\
\text { (długość kampanii): }\end{array}$ & $\begin{array}{l}\text { duże wahania } \\
\text { wzrost z } 210 \text { do } \\
557 \text { t/os. } \\
\text { wzrost z } 87 \text { do } 118 \\
\text { dni }\end{array}$ \\
\hline $\begin{array}{l}\text { rentowność } \\
\text { przychodów: }\end{array}$ & +/- ; średnio 9,6\% \\
\hline
\end{tabular}

\section{Rysunek 4}

Wpływ polityki rządu na sektor cukrowniczy: okres III Źródło: Jak na rysunku 2.

wiązała się z modernizacją czynnych zakładów - duże nakłady inwestycyjne w cukrowniach doprowadziły do postępu technologicznego, który miał wpływ na wydajność pracy oraz wykorzystanie zasobów produkcyjnych [Szajner 2009, s. 444]. Okres reformy charakteryzował się dużymi wahaniami cen zbytu cukru oraz poziomu marży przetwórczej, czego efektem są zmienne wyniki finansowe [Chudoba 2010, s. 70] - rysunek 4. 


\section{Podsumowanie i wnioski}

W latach 1990-2013 sektor cukrowniczy funkcjonował w często zmieniających się uwarunkowaniach prawnych, co miało istotny wpływ na strukturę rynku cukru, działania przedsiębiorstw, a w efekcie na ich wyniki. Utrwalona wraz $\mathrm{z}$ wejściem do Unii Europejskiej oligopolistyczna struktura rynku cukru w Polsce w połączeniu ze skuteczną i głęboką restrukturyzacją i modernizacją sektora, której towarzyszył duży postęp technologiczny, przyczyniły się do znaczącej poprawy wykorzystania zasobów, co w połączeniu z wysokimi cenami cukru wpłynęło na bardzo wysoką rentowność branży w ostatnich latach. Nie osiaggnięto jednak względnej stabilizacji cen.

Wraz ze zniesieniem limitowania produkcji cukru w 2017 roku i rozpoczęciem funkcjonowania w warunkach wolnorynkowych sektor czekają kolejne wyzwania. Potencjał produkcyjny cukrownictwa jest duży i ma szansę się rozwinąć, ale jednocześnie będzie poddany bardzo silnej konkurencji, krajowej i zewnętrznej, zarówno ze strony producentów cukru, ale również chociażby producentów izoglukozy. Taka perspektywa determinuje potrzebę podjęcia jak najszybszych działań dostosowawczych.

Z uwagi na ograniczoną objętość publikacji skoncentrowano się jedynie na zarysowaniu podstawowych zależności pomiędzy regulacjami prawnymi a ich wpływem na strukturę i wyniki sektora cukrowniczego w Polsce. Pogłębione badania zależności między składowymi modelu S-C-P mogłyby być przydatne jako podstawa analizy sytuacji sektora po zniesieniu kwot w 2017 roku.

\section{Literatura}

ARTYSZAK A., 2009: Następstwa trzech lat obowiazywania reformy rynku cukru w UE, Problemy Rolnictwa Światowego, t. 8(23), s. 5-9.

BLAUG M., 2000: Teoria ekonomii. Ujęcie retrospektywne, Wydawnictwo Naukowe PWN, Warszawa.

CARLTON D., PERLOFF J.M., 2005: Modern Industrial Organization, Pearson Addison Wesley, Boston.

CHUDOBA Ł., 2010: Wplyw reformy rynku cukru w Unii Europejskiej na polski sektor cukrowniczy, Gazeta Cukrownicza, nr 3, s. 68-71.

COASE R.H., 2013: Firma, rynek i prawo, Oficyna Wolters Kluwer Business, Warszawa.

CZYŻEWSKI A., POCZTA-WAJDA A., 2011: Polityka rolna $w$ warunkach globalizacji. Doświadczenia GATT/WTO, Polskie Wydawnictwo Ekonomiczne, Warszawa.

FOSS N.J., 1996: Research in Strategy, Economics and Michael Porter, Journal of Management Studies, nr 33(1), s. 1-24.

GORYNIA M., JAWORSKA B., OWCZARZAK R., 2005: Zarzqdzanie strategiczne jako próba syntezy teorii przedsiębiorstwa, Ekonomista, nr 5, s. 595-619.

International Sugar and Sweetener Report, F.O. Licht, nr 5/2013. 
IWAN C., 2007: The Impact of Privatization With Foreign Involvement on the Restructuring Process of the Sugar Industry in Poland, Peter Lang Publishing Inc.

KONDRAKIEWICZ T., 2000: Holdingi w przemyśle cukrowniczym. Procesy dostosowawcze do integracji z Uniq Europejska, Wydawnictwo UMCS, Lublin.

LEE C., 2000: SCP, NEIO and Beyond, Working Paper Series of Nottingham University Business School 5, http://file.icsead.or.jp/user03/834_212_20110622120417.pdf (data dostępu: 08.05.2013)

MUCHA M., 2010: Stan i perspektywy branży cukrowniczej w Polsce. Podsumowanie reformy regulacji rynku cukru w Unii Europejskiej w latach 2006/2007-2009/2010, Gazeta Cukrownicza 3, s. 64-67.

PIETRZAK M., 2014: Problem geograficznego zakresu rynków/sektorów w dobie globalizacji i regionalizacji, Zagadnienia Ekonomiki Rolnej 1, s. 3-20.

PORTER M.E., 1981: The Contributions of Industrial Organization to Strategic Management, Academy of Management Review, nr 6(4), s. 609-620.

PORTER M.E., 1998: Strategia konkurencji. Metody analizy sektorów i konkurentów, Polskie Wydawnictwo Ekonomiczne, Warszawa.

Rynek cukru. Stan i perspektywy, nr 40, IERGŻ, 2013.

SCHERER F.M., 1970: Industrial Market Structure and Economic Performance, RAND McNALLY College Publishing Company, Chicago.

SCHMALENSEE R., 1989: Inter-Industry Studies of Structure and Performance, [w:] R. Schmalensee, R.D. Willig (red.), Handbook of Industrial Organization, vol. II, Elcevier, Amsterdam.

SZAJNER P., 2009: Ocena wplywu reformy systemu regulacji rynku cukru w Unii Europejskiej na polski przemyst cukrowniczy, Problemy Rolnictwa Światowego, t. 8(23), s. $182-191$.

SZAJNER P., 2012: Wplyw reformy regulacji rynku cukru w UE na efektywność polskiego przemysłu cukrowniczego, [w:] J. Sokołowski, M. Sosnowski, A. Żabiński (red.), Polityka ekonomiczna, Wydawnictwo Uniwersytetu Ekonomicznego we Wrocławiu, Wrocław, s. 444-453.

TIROLE J., 1988: The Theory of Industrial Organization, The MIT Press, Cambridge MA.

URBAN ST., 1995: Perspektywy rozwoju przemyslu cukrowniczego w Polsce, Gazeta Cukrownicza, nr 1, s. 16-17.

WOSZCZYNA J., WYSZYŃSKI Z., 2000: Rynek cukru, [w:] E. Majewski, G. Dalton, Strategiczne opcje dla polskiego sektora agrobiznesu w świetle analiz ekonomicznych, SGGW Centrum Naukowo-Wdrożeniowe, Warszawa.

WYKRĘTOWICZ S., 1997: Najnowsze dzieje cukrownictwa w Polsce (1944-1989). Studium historyczno-ekonomiczne, Muzeum Narodowe Rolnictwa i Przemysłu Rolno-Spożywczego, Poznań-Szreniawa. 


\title{
The influence of market regulations on the functioning of sugar industry in Poland
}

\begin{abstract}
In the period 1990-2013 sugar industry in Poland faced numerous legal transformations, shifting from nearly free-market conditions into a strongly regulated sector. Changes of the sugar industry regulations had a significant impact on the structure of the sugar market, companies' actions and, as a result, on their performance. Accession to the European Union and the reform of the sugar regime conducted from 2006 to 2010 on the initiative of the European Commission involved deep restructuring and modernization of the factories, which caused growth of their productivity. However, prices of sugar in the EU and in Poland are much higher than prices on the world market.
\end{abstract}


